\title{
Gabriel Biel as Transmitter of Aquinas to Luther
}

LAWRENCE F. MURPHY, S.J.

Did Gabriel Biel, the last of the scholastics (d. 1495) and indirectly an influential teacher of Martin Luther, correctly interpret the teaching of St. Thomas Aquinas on the material element of original sin? Biel, following the Sentences of Peter Lombard (the Master), treats the essence of original sin in Distinction Thirty of Book Two of the Collectorium. He distinguishes two "opposite opinions of weight" and a third opinion "as it were intermediate," which he ascribes to Alexander (of Hales), St. Bonaventure, and St. Thomas Aquinas. This latter opinion he interprets as understanding concupiscence to be a positive morbid quality that is the material element of original sin. And he understands St. Thomas as teaching that original sin is a "corrupt habit of sorts." Did he correctly interpret and explain the teaching of St. Thomas? I think not, and this essay will offer my reasons. I shall also discuss briefly on the significance of this failure for the theological development of Martin Luther. ${ }^{1}$

Biel, in Question One, after briefly outlining the doctrine of the Master on the essence of original sin, immediately asks whether original justice in our first parent is a supernatural gift. He treats at some length, following Scotus and Ockham, the notion of original justice and concludes that original justice was a supernatural gift, infused into the will of the first parent to effect perfect tranquility in all the powers of the soul. We need not delay here as the topic is not immediately relevant to our concerns.

In Question Two Biel asks whether original sin is something positive in (a) the soul or (b) the flesh. He notes three basic positions on this question:

With regard to the first it must be noted that concerning the matter of original sin, namely, its essence, cause, acquisition, and remission and related matters, there are two opposite opinions of weight each of which has many followers, and a third in the middle as it were. One is that of the Master. The second is that of blessed Anselm in this book on the virginal conception. ${ }^{2}$

Biel first presents the opinion of Peter Lombard at some length. He summarizes the Master's teaching as follows: 
And thus it is clear, according to this opinion, what original sin is in reality for it is a morbid quality of the soul, namely, the vice of concupiscence, and also how it is contracted from one's parents, for it is caused by a morbid quality of the flesh which our flesh contracted from the lustful concupiscence or ardor of the parents as they fuse together in sowing the seed of a child. ${ }^{3}$

The answer of the Master to Biel's question is that original sin, which is identical with concupiscence, consists of two morbid qualities, one in the flesh, and one in the soul. St. Anselm, however, holds quite a different opinion, which Biel presents in this way:

This holds that original sin does not mean something positive. It is the lack of original justice that should be present, since it was received and lost in the first parent. Sin formally is injustice. But injustice is nothing else than the lack of justice that should be present. ... It is clear that original sin is the lack and privation of original justice that should be present. For all sons and daughters of Adam, who were generated according to the laws of propagation, are debtors of original justice, because Adam received original justice for himself and for the whole nature which was then in him. ${ }^{4}$

God decreed to give original justice to all Adam's descendants also as a free gift, but Adam lost it for them. For St. Anselm, therefore, original sin is not something positive (not concupiscence, not a vice of the soul, not a stain in the flesh), but merely the privation of original justice. ${ }^{5}$

Biel next presents a third opinion, that of Alexander (of Hales), which he describes as a kind of intermediary position and which, he states, might "reconcile in some way" the opinions of the Master and St. Anselm. He asserts that it is held by St. Bonaventure and by St. Thomas and refers specifically to I-II, q. 82 of the Summa Theologiae. He states it this way:

This opinion holds that in original sin two elements are considered. One is the material, namely, the concupiscence which is a certain morbid quality, especially that which inheres in the soul. The second is formal and is a lack of the original justice that ought to be there. ${ }^{6}$

Biel illustrates this distinction of the material and formal elements with an actual sin of homicide. In this sin we find an interior decision of the will, a positive act to commit murder, and the exterior act of killing. The sin's formal element is the lack of justice in the interior and exterior act, which acts constitute the material element. Biel's example would seem to indicate that he understands Alexander to mean that original sin consists of two positive qualities (one in soul and one in body) as the material element, which formally as sin are lacking original justice that should be present. His summary of Alexander's opinion seems rather vague. ${ }^{7}$

Biel then turns more explicitly to St. Thomas: 
Blessed Thomas, as cited above article one, says that original sin means a privation of original justice and, along with this, an inordinate disposition of the parts of the soul. Thus it is not a pure privation, but it is a corrupt habit of sorts, but not an infused habit, nor an acquired habit, but a habit that is inborn due to our corrupt origin. and in article three he says that original sin materially is concupiscence but formally it is a defect of original justice. ${ }^{8}$

Biel seems to understand in his presentation of this opinion that, because the authors speak about the material element of concupiscence, this necessarily involves a positive morbid quality. It is on this presupposition that Biel goes on to use the opinion outlined above to reconcile the opinions of Peter Lombard and St. Anselm:

For the Master does not exclude the privation of original justice from original sin.

Nor does St. Anselm deny a morbid quality, namely concupiscibility, is contracted in the children from the polluted flesh of the parents, although he does not express it in these words. ${ }^{9}$

Therefore, it seems clear that Biel interprets St. Anselm, along with Alexander of Hales, St. Bonaventure, and St. Thomas as teaching that some kind of positive morbid quality constitutes the material element of original sin, and that this is concupiscence. For it is on these grounds that he sees this middle position as agreeing with Peter Lombard, who quite clearly holds that concupiscence is a positive vice, not a privation, in the flesh and the soul.

Biel's attempt to reconcile conflicting opinions and doctrines is admirable and worthy of praise. But in the present case is it not too facile and simplistic? Are these opinions not irreconcilable and the opposition between them beyond the level of mere words?

What does St. Thomas teach in the passage to which Biel alludes (Summa I-II, q. 82, art. 1)? In Article One he asks, "Is original sin a habit?" Before replying, St. Thomas takes up some arguments denying original sin is a habit, of which the first is especially noteworthy since it directly involves St. Anselm:

1. It seems that original sin is not a habit. For original sin is the lack of original justice, as Anselm notes. As such, then, original sin is a type of privation; privation and habit are opposites. Therefore original sin is not a habit. ${ }^{10}$

Thus St. Thomas seems to be aware of St. Anselm's rejection of the Master's doctrine that original sin is a permanent and positive quality in the soul (habit), and his position that it is merely a privation of original justice. Does he agree?

His reply to this objection shows that he does not:

Hence: 1 . As in bodily illness there is privation, in that the balance of health is upset, yet also something positive, the disturbed bodily humours, so also in 
original sin there is privation, the lack of original justice, yet along with this there are the disturbed powers of the soul. Thus it is not pure privation, but also a corrupt habit of sorts. ${ }^{11}$

Here we find the exact words quoted by Biel, "Thus it is not a pure privation, but it is a corrupt habit of sorts." St. Thomas, therefore, does not follow the doctrine of St. Anselm, if St. Anselm wants to reduce original sin purely and solely to the privation of original justice and say nothing about the resulting inordinate disposition of the parts of the soul. But does if follow that St. Thomas means, as Biel thinks, some positive morbid quality? ${ }^{12}$ Has Biel weighed carefully the notion of "corrupt" in "corrupt habit?"

The third objection also deserves attention:

Further, as for moral evil act always comes before habit, since a bad habit is not infused but acquired. No act, however, precedes original sin. So it is not a habit. ${ }^{13}$

To this St. Thomas replies:

This objection argues in terms of habit inclining a power toward a definite activity. Original sin is not this kind of habit. While is may be true that some bent towards disordered activity is a consequence of original sin, it is not true that it follows directly from original sin, but rather indirectly, in so far as original sin removes the restraint of original justice, which kept disordered impulses in check; thus also a tendency towards physical malfunctioning may follow as a side effect from organic disease. Nor should it be said that original sin is a habit either infused or acquired by an act (except of the first parent, not of anyone else); it is a congenital habit arising from a vitiated origin. ${ }^{14}$

Here we find the source of Biel's words, “... but not an infused habit, nor an acquired habit, but a habit that is inborn due to our corrupt origin." But what kind of habit is this, since St. Thomas has rejected the common notion of habit as a positive quality inclining to an act like a vice or virtue? We note that St. Thomas repeats his analogy from bodily illness. Is this some positive quality added to the powers of the soul as Peter Lombard seems to understand concupiscence?

Let us consider St. Thomas' basic answer to this question. And first the Sed Contra should be noted:

On the other hand, Augustine in his work on infant baptism declares that because of original sin infants, though not actually experiencing concupiscence, have the aptitude for it. But aptitude implies the presence of some habit. Original sin, then, is a habit. ${ }^{15}$

This text indicates the motivation of St. Thomas in this article. He is concerned (it may be against St. Anselm) to preserve with Peter Lombard and St. 
Augustine the tradition, with its roots in Scripture, that relates original sin inseparably with concupiscence in some way.

This leads us to the body of the article:

Reply: Habit, as has been previously stated, is twofold. One kind is that by which a power is bent on a definite activity; thus science and virtue are called habits. Original sin is not a habit in this sense.

In the other sense of the term, habit means a modification of a nature composed of many elements, according as it bears itself well or ill towards something, and chiefly where such a disposition becomes as it were second nature, as in the case of sickness or health. In this way it is that original sin is a habit. For it is a disordered disposition growing from the dissolution of that harmony in which original justice consisted.

An analogy is found in bodily illness, a kind of disordered disposition of the body upsetting the balance in which good health consists. Likewise original sin is called a SICKNESS OF NATURE. ${ }^{16}$

First of all, we note again the concern of St. Thomas to preserve with Peter Lombard and St. Augustine the biblical data of revelation. When at the end of the passage he refers to original sin as a "disease of nature," he repeats one of the Master's phrases. ${ }^{17}$ It is important to note and weigh the distinction St. Thomas makes in this passage. He clearly describes original sin as a habit. But he excludes it from those clearly positive qualities such as virtues and kinds of knowledge that incline powers to acts. Rather he uses the word "habit" for a disposition like health or sickness. It is necessary to evaluate carefully the meaning of this notion of "disordered disposition." Does it add something positive, a new metaphysical being over and above the powers of the soul? Biel has certainly portrayed the words of St. Thomas accurately, but has he weighed them properly? Matter is disposed to form, the soul is disposed to grace, but does this add a positive quality ${ }^{18}$

Biel also refers to St. Thomas' teaching in the third article of this question of the Summa when he says, "Original sin materially indeed is concupiscence but formally it is the loss of original justice." In the third article St. Thomas asks "Is original sin concupiscence?" He replies:

... The whole order of original justice lay in man's will being subjected to God. This subjection first of all and chiefly was through the will, to which belongs the moving of all the other powers towards the final end, as previously indicated. From the will's turning away from God, then, the disorder in all the other powers of the soul followed.

So then the lack of original justice subjecting the will to God is what is formal in original sin. Every other disorder in the various powers of the soul is like what is material in original sin.

The disorder of the other powers of the soul is chiefly noticeable in an unruled turning to goods that pass away, which disorder can be designated by the term 'concupiscence'. So then original sin materially is concupiscence, yet formally it is the lack of original justice. ${ }^{19}$ 
It is clear that Biel quotes the exact words of St. Thomas. Biel gives no explanation of how he understands St. Thomas' conception of concupiscence as the material element of original sin. Does he mean that concupiscence is a vice, a positive morbid quality, like a pump added to an already swiftly flowing river to increase its speed of flow down-stream?

T.C. O'Brien, editor of the Blackfriars edition of the Summa, notes that "The present article is concerned with the reconciliation of Augustine and Anselm on the nature of original sin." ${ }^{20}$ And he offers this interpretation of article 3:

... In actual sin there is a turning away from God (aversio) and a turning toward a created good (conversio). But art. 1 of this question indicates that original sin is entirely a PRIVATION. It does not turn the will against God; it is the lack of the positive relationship to him found in original justice. Nor does it mean a POSITIVE disposition in the powers of the soul to created goods, but the removal of the restraint given by original justice. ${ }^{21}$

O'Brien then sees original sin as "entirely a privation."

Dom O. Lottin points out that St. Albert the Great, St. Bonaventure and St. Thomas all used the same terminology of the formal and material element in original sin - but in three quite different ways! Lottin summarizes St. Thomas as follows:

St. Thomas reacts against both his predecessors; for in his eyes the material element is a passive element. The divergence arises from what he said earlier about the role of the will: the will exercises on the sensitive appetite a causality that is not only final but efficient; for to direct it to the rational end which it seeks the will must move it there. And hence concupiscence, the absence of the check on the senses, speaking properly, can only be an effect of the disordered will; and to speak of effect is to speak of an extrinsic element. On this basis Thomas Aquinas thus implicitly contradicted both Bonaventure and Albert the Great who introduced concupiscence as an intrinsic and essential element of original sin. ${ }^{22}$

Throughout his presentation of St. Thomas and his summary of scholasticism, Lottin argues that St. Thomas really believes that concupiscence is an effect of the will's disorder and agrees with Anselm. ${ }^{23}$ St. Thomas, says Lottin, calls original sin a habit, not an operative habit, but a bad disposition like an illness. But since an illness is the unbalance of the bodily forces which, set in order, would have constituted health, original sin is the loss of the harmony that constituted original justice. Now an illness is defined in its species by its efficient cause, and illnesses differ specifically according to the causes that engender them. A being is specifically defined by its form, and, in a habit like original sin, the form is defined by the efficient cause. Hence to define original sin specifically, its efficient cause must be defined. Now the task of the will was to maintain the submission of the soul to God, to keep 
original justice, which it lost by turning away from God. The will is the efficient cause. The disorder in the other faculties was caused by the disorder of the will. Lottin concudes as follows:

Why then does St. Thomas not simply conclude that concupiscence or the disorder of the senses is the effect of original sin?

There is no doubt about the reason. To assert that concupiscence is the effect of the privation of original justice would be to condemn the Augustinian formula. For, just as it is impossible that cause and effect constitute one and the same reality, it would have been necessary logically to exclude concupiscence from the essence of original sin, while the Augustinian theory saw in it the essence, and the whole essence, of sin.

We think that the secret sympathy of St. Thomas, the profound orientation of his thought, led him towards the pure and simple formula of St. Anselm of Canterbury. But he was held back from this path by his repect for the so greatly venerated authority of St. Augustine. Hence he wanted to find a necessary expedient to maintain the Augustinian formula while at the same time stressing that concupiscence can only be a secondary element of original sin. ${ }^{24}$

I have presented this argumentation of Lottin to show how difficult it is to interpret carefully St. Thomas' understanding of the formal and the material element in relation to Anselm, Bonaventure and Albert. It is difficult to determine with accuracy whether Lottin sees habit as positive or privation. Lottin does not expressly examine whether the habit of original sin is merely a privation or whether it is positive in the sense of a new metaphysical entity beyond the sensitive powers themselves, which surely are positive.

To resume the text of St. Thomas, it will be useful to note the first objection to the identification of original sin and concupiscence:

It seems that original sin is not concupiscence. For every $\sin$ is against nature, as Damascene states. Concupiscence, however, is according to nature, since it is the proper activity of the concupiscible part, a natural power. Concupiscence, then, is not original $\sin .^{25}$

In his reply St. Thomas does not deny concupiscence is natural. He says:

Hence: 1. Man's nature requires that the concupiscible appetite be ruled by reason. Its activity, then, is natural to the extent that it observes the order of reason. When concupiscence exceeds the bounds of reason it is in man against nature. Such is the concupiscence belonging to original sin. ${ }^{26}$

For St. Thomas, therefore, the principal element in original sin is the loss of original justice. But for him the loss of original justice and unbridled concupiscence are co-relatives and necessarily connected. For him concupiscence is natural. "The material element" does not mean that some positive vice or force inclining to act has been added. "The material element" means a privation, a defect, a failure, a lack of the controlling will because the will has 
turned from God and no longer directs the sensitive appetites to God. So Biel is correct in seeing in St. Thomas a middle position between Peter Lombard and St. Anselm who, as Biel presents it, thinks only of the loss of original justice as constituting original $\sin .{ }^{27}$

Has Biel correctly understood the teaching of St. Thomas? If Biel wishes to use the teaching of St. Thomas, thinking it is really in agreement with that of the Master, as a bridge to reconcile St. Anselm's doctrine, then I think he has not.

Biel describes the teaching of the Master in these terms:

This seems to be the opinion of the Master. The will of Adam, sinning in its own flesh, caused a certain morbid quality following on the bent of the will. This is given various names: the tinder of sin, concupiscence or concupiscibility, the law of the members, the disease of nature, the tyrant in the members, the law of the flesh. It is a kind of weight in the flesh exciting sensual movements and inclining the soul to take delight in the flesh and thus delaying and repressing spiritual delights, as that passage of Wisdom 9 [:15] states, "The body that is corrupt weighs down the soul." It weighs it down because of that morbid quality in the flesh. And, according to some people, that quality is not remitted in its essence even if it is lessened in its effect. This means that grace can be so strong in the soul that it inclines it more to the things that are above than the tinder does to the things that are below. Yet it does not remove the tinder in its essence because it is not opposed to the tinder which is in the flesh. But grace is in the soul as if a pebble were bound to the wings of a bird. No matter how great the force of motion in the wing, the weight of the stone would never be lessened. Yet the gift could repress the functioning and impede the flight of the bird, because the contrary force would overcome in its effect. ${ }^{28}$

Here Biel is speaking of the quality or stain in the flesh, which causes that in the soul. His description of it as "a certain morbid quality," "a weight in the flesh arousing sensual movements and inclining the soul" surely fits the description, not of a disposition, but of a habit "by which a power is bent on a definite activity," as St. Thomas describes it, and which, he said, original sin is not. It is interesting how Biel switches the comparison at the end and makes concupiscence the bird and grace the small stone. Even so, the notion of a bird soaring indicates more an operative habit, a vice.

When Biel comes to the effect of the sin in the flesh on the soul, he says:

From that morbid quality of the flesh in the infusion of the soul another morbid quality is caused in the soul which is a vice inclining the soul to unbridled concupiscence ... And each quality is called concupiscence or concupiscibility, tinder, etc. and that concupiscibility in the soul is original sin ... And although without that quality of its own or that of the flesh the will would naturally be prone to concupiscence and to delight in the senses ..., yet not so unrestrainedly and generally apart from God as now. ${ }^{29}$

Biel clearly states that concupiscence is a vice, a positive morbid quality, and sees the Master teaching it as something positively added on to increase the 


\section{4 / Renaissance and Reformation}

weight of concupiscence. Biel repeats this statement in his summary of the opinion of the Master:

And hence it is clear what original sin is in fact according to this opinion: it is a morbid quality of the soul, namely the vice of concupiscence. ${ }^{30}$

And Biel's later argumentation confirms that he sees concupiscence as a positive quality. ${ }^{31}$

In this whole matter it is important to notice what Biel leaves out in his presentation of St. Thomas. In his general description of the third reconciling opinion, Biel asserts:

This opinion holds that in original sin two things are being considered. One is the material element, namely concupiscence, which is a kind of morbid quality especially that which inheres in the soul. ${ }^{32}$

For Biel the ability of this opinion (here described in general terms as if Alexander, St. Bonaventure and St. Thomas all held it) to reconcile rests on the twofold morbid quality in the flesh and the spirit. A serious difficulty in understanding Biel's thought arises from the fact that, in his description of Alexander's view, he does not explicitly ascribe to Alexander such a twofold understanding of concupiscence. What he sees in Alexander is the latter's description of concupiscence as the material element. Hence Biel summarizes,

And this seems to be the intent of Alexander in the place alleged when he says that original sin consists of both guilt and penalty. The guilt is the lack of justice or a kind of deformity by which the soul itself is disfigured. And later, when he says that original sin is concupiscence itself, the predication is material. But when he says it is a stain or deformity contracted by origin from our first parents, the prediction is formal. And it follows that in one sense original sin is punishment, in another it is guilt. As a lack of justice it is guilt. As concupiscence it is a penalty. ${ }^{33}$

Does Biel see Alexander (and St. Thomas) teaching that concupiscence is a vice, a twofold positive quality?

A suggestion that he does is found in Biel's reconciliatory study of St. Anselm. I do not intend to present Biel's argument but merely to point out his conclusion:

Therefore, he places something in the body, something in the soul, and along with this the debt of justice. He states that these three remain in the offspring. Thus he does not deny that something positive follows the sin of our first parents both in the body and in the soul of the offspring. ${ }^{34}$

Biel, therefore, sees St. Anselm teaching "something positive" both in the soul and the body of the descendant of Adam. He recognizes, however, that 
St. Anselm would not identify them as of the essence of original sin. It is on this basis that he asserts that, "The dispute [between Peter Lombard and St. Anselm] is more over words than reality." 35

If, therefore, it seems reasonable to assume that Biel sees Alexander and St. Thomas teaching such a doctrine, we must assert that Biel is incorrect in the case of St. Thomas. The communication of original sin is explained in the Summa in terms of the communication of human nature. St. Thomas does not mention passion dominating the conjugal act, contaminating the flesh, causing a morbid quality in the flesh that inclines the soul to delight in the flesh, that infects in turn the infused soul. Flesh, seed, intercourse - all that is involved in human reproduction - transmit sin as they transmit human nature. Generation as an act of nature sufficiently explains our link and unity with Adam. Because of Adam the nature that generates does not have what it should have and hands on a similar nature to the person who receives it.

St. Thomas states his position quite clearly in this text:

Reply: One thing can be in another in two ways, either as in its cause, principal or instrumental, or as in its subject. The original sin of all men existed in Adam as in its first principal cause, according to St. Paul's text, IN WHOM ALL HAVE SINNED. As in its instrumental cause original sin is in the semen. The reason for this is that original sin is transmitted to offspring together with human nature through the power of the semen. Original sin can in no way be in the body as in its subject, but only in the soul ... ${ }^{36}$

Original justice was a gift to human nature, but instead of being passed on with human nature, its absence was passed on. ${ }^{37} \mathrm{St}$. Thomas turned from the older theological tradition that stressed the prominence of concupiscence and that gave to original sin a positive character with positive effects in man. For the older tradition "An actual bent towards moral evil and the rooted disorder in human nature take on the aspect of habitual perversity, proneness to evil, a vice or complex of vices." 38 But in St. Thomas, says O'Brien, "There is no positive entity communicated by actual concupiscence in the sexual act. Original sin begets no complex of vices, no direct inclination to sin in man. Not only the absence of original justice but concupiscence itself is a privation, a lack of the ordered desires present in human nature at the beginning." $39 \mathrm{St}$. Thomas' understanding of the essence and transmission of original sin rests on the principle that all men born in Adam can be looked upon as one man, that they receive their nature from him.

But could one not object against the interpretation of O'Brien that he stresses too greatly the privative aspect of original sin? For Aristotle and St. Thomas an entitative habit like beauty and health is clearly a quality and positive. Is sickness merely a privation? Is it not also a positive quality? Sweet and sour are opposite qualities but sour is not a privation of sweet. Is a diseased eye simply a privation of health? Is it not the role of the doctor to treat the sickness in the eye? Does St. Thomas not contrast entitative habit and 


\section{6 / Renaissance and Reformation}

privation as opposites (art. 1, ad 1)? Is entitative habit merely an extrinsic denomination? Surely not! St. Thomas (art. 3) distinguishes between the efficient cause of the habit of original sin, namely the privation of original justice, and its effect, namely the actual disordered disposition or corrupt habit. "Of sorts," of course, because this is an attempt by analogy to get some understanding of a revealed mystery. Thus, the text of St. Thomas indicates the corrupt habit is positive. But not in the sense of an operative habit! Biel, not St. Thomas, asks the question whether original sin is positive. Biel, I believe, is correct in asserting that St. Thomas teaches that original sin is something positive.

In conclusion, therefore, did Gabriel Biel correctly interpret the teaching of St. Thomas Aquinas on the material element of original sin? Biel's basic concern is excellent. He wants to reconcile the three conflicting opinions and preserve unity of doctrine among the authorities. He sees that Peter Lombard and St. Anselm both recognize the basic pieces of the puzzle: sin, concupiscence, and original justice. He concludes that the dispute is really over words and not reality. But this approach is too simplistic. Biel presumes, without supplying evidence, that St. Thomas (and St. Anselm) teach a morbid quality in the flesh. He sees St. Thomas speaking of a "corrupt habit of sorts" and leaves the impression that St. Thomas is teaching what the Master holds. Even if Biel is correct in asserting that St. Thomas' "corrupt habit" is something positive, he does not sufficiently explain what St. Thomas means. Nor has he given any indication of the differences and complexity of the third opinion's understanding of the formal and material element. Biel's presentation, we conclude, is a simplistic and partially incorrect presentation of scholasticism.

Modern theologians approach the traditional Church teaching about original sin with a new set of problems because the scientific hypothesis of polygenism questioned the fundamental principle of our unity of nature in Adam. ${ }^{40}$ But Peter Lombard (adhering most closely to the doctrine of St. Augustine), St. Anselm, St. Thomas Aquinas, and Gabriel Biel - representatives of both the patristic and medieval tradition - all agree that the sin of Adam has left mankind in interior disorder of some kind. In trying to preserve harmony of doctrine, in his respect for the theological traditions, Biel surely is to be commended. But I conclude that, in his attempt to reconcile the conflicting theologies of his time, Biel has not presented the teaching of St. Thomas with sufficient accuracy.

What historical significance does this conclusion hold? Is it correct to see Biel as giving renewed weight to the opinion of St. Augustine and thus preparing the way for Luther and Lutheran emphasis on concupiscence? I think not. First of all, Biel presents accurately the three general opinions as they came to him and were held at his time. Secondly - and most important - 
the early Luther of 1509 shows remarkable awarness of St. Anselm's view that original sin in every way is privation and is in agreement with this view. ${ }^{41}$ Hence Biel's failure to present with complete accuracy St. Thomas' teaching on this point cannot have influenced Luther in any significant way. Thirdly, in the light of contemporary scholarship one must exercise caution when speaking about preparing the way for Luther. That Luther and Lutherans after 1518 defended Augustine's identification of concupiscence and the essence of original sin seems clear enough. But even if the Council of Trent condemned the identification of concupiscence and original sin, recent interpretations of Trent suggest the two views were not utterly irreconcilable. ${ }^{42}$ That Luther and Lutherans taught or teach a theory of non-imputation of sin, in the sense that sins are not truly forgiven, seems untenable in the light of recent ecumenical discussions. ${ }^{43}$ This conclusion is confirmed in the movement among Roman Catholic theologians to have the Roman Catholic Church recognise the Augsburg Confession which reached a climax in 1980 on the occasion of the Confession's 450th anniversary. ${ }^{44}$

Saint Mary's University, Halifax

\section{Notes}

1 Gabriel Biel, Collectorium Super IV Libros Sententiarum Gulielmi Occam, 2 vols. (Tübingen, 1501; rpt. Hildesheim, 1977). Biel, Coll., II, d. 30, q. 2, art, 1. I came to this conclusion independently while studying Luther's marginal notes of 1509 to this passage of the Sentences. H. Denifle, Luther und Luthertum in der Ersten Entwicklung (Mainz, 1904-06) can be credited with raising the question in modern times of Luther's relation to scholasticism. Denifle held a very dim view of Luther's knowledge of scholasticism and of Biel's scholasticism, which he considered uncatholic decline. Heiko Oberman, The Harvest of Medieval Theology: Gabriel Biel and Late Medieval Nominalism (Grand Rapids, Michigan, 1962) defends Biel against the charge of haphazard knowledge and unreliability as a late medieval text book (Denifle) and considered Biel basically catholic. Harry McSorley, Luther Right or Wrong?: An Ecumenical-Theological Study of Luther's Major Work, The Bondage of the Will (New York, 1969), p. 185, note 10 indicates that the positions of Denifle and Oberman are closer than "the dangerous generalizations" of mere decadence against balanced synthesis. Scholasticism was quite diverse and Luther's relation to it more complicated than was thought earlier. At any rate neither Denifle, nor Oberman, to the best of my knowledge, have undertaken the precise study I am attempting here.

2 Ibid., art. 1, note 1:

Quod primum notandum quod de materia originalis peccati eius scilicet quidditate causa contractione ac remissione et hec concernentia sunt due opiniones extreme solennes quarum utraque habet plurimos imitatores. Et tertia quasi media. Una est magistri. Altera beati Anselmi in libro de conceptu virginali....

Biel states the fundamental importance of these three opinions for the whole treatment of original sin (d. 30-35).

3 Loc. Cit:

Et ita patet secundum hanc opinionem quid sit peccatum originale secundum rem quia est qualitas morbida anime, vitium scilicet concupiscentie et quomodo contrahitur a parentibus quia causatur a qualitate morbida carnis quam caro contraxit ex libidinosa concupiscentia sive ardore parentum coeuntium in prolis seminatione.

Cf. Lawrence F. Murphy, S.J. "Martin Luther and Gabriel Biel: A Disagreement about Original Sin," Science et Esprit, 32 (1980), 52-72. 


\section{8 / Renaissance and Reformation}

4 Loc. Cit.:

Hec tenet quod peccatum originale non dicit aliquid positivum. Sed est carentia iusticie originalis debite ut accepte in primo parente et in ipso amisse. Cum enim peccatum formaliter est iniusticia, iniusticia autem non est nisi carentia iusticie debite ut ibi declarat Anselmus et in de casu diaboli c. 16. Patet quod peccatum originale est carentia et privatio originalis iusticie debite inesse. Sunt enim omnes filii et filie Adam secundum leges propagationis genite debitores originalis iusticie quia Adam accepit iusticiam originalem pro se et tota natura que tunc erat in eo.

Biel sees this opinion followed by Scotus, Ockham, Gregory of Rimini and their followers.

5 Biel, while he states here clearly enough that for St. Anselm original sin is not something positive, and while he stresses in his explanation the divine decree to give original justice to all descendants of Adam - as if that were all the explanation needed - does not expressly state that St. Anselm denies the identity of original sin and concupiscence, and does not clearly indicate that St. Anselm in fact rejects the explanation based on passionate concupiscence and the consequent stain in the flesh. It is surprising that Biel does not make the contrast more accurately. Perhaps, since he is summarizing Ockham, he presumes his reader knows St. Anselm's view. In Art. 2, concl. 5 he asserts:

Each opinion, that the tinder is included in the essence of original sin as its material element, and that it is not included but is joined in fact, is probable. The conclusion is clear for saints and illustrious doctors defend each opinion.

[Utrumque et fomitem includi in ratione peccati originalis tamque materiale et ipsum non includi sed esse annexum de facto est probabile. Patet conclusio quia utramque partem tenent viri sancti et doctores famossisimi.]

Presumably the opinion that the tinder is not included in original sin, i.e., that concupiscence is not identical with original sin, is the opinion of St. Anselm. In art. 2, concl. 7 Biel says:

Conclusion seven following the opinion of blessed Anselm. One morbid quality seems to suffice which has the flesh as subject. Proof. That quality is posited because of the unrestrained inclination of the will to concupiscence which we experience. To explain this fact a quality of the flesh suffices. There is no need for one in the soul and its part. And plurality should be avoided where necessity does not demand it.

[Septima conclusio tenendo opinionem beati Anselmi. Una qualitas morbida videtur sufficere que subiectatur in ipsa carne. Probatur conclusio quia illa qualitas ponitur propter inclinationem voluntatis effrenatam ad concupiscendum quam experimur. Sed ad hoc salvandum sufficit qualitas carnis absque hoc quod talis ponatur in anima et eius parte. Et cavenda est pluralitas ubi non urget necessitas.]

But where does St. Anselm teach such a positive quality in the flesh?

6 Tertia est opinio Alexandri par 2 q. 122 que est quasi media inter illas secundum quam possent aliquo modo concordari due predicte opiniones magistri et Anselmi. Hanc sequitur beatus Thomas prima secunde q. 82 et sanctus Bonaventura in secundo scripto presenti distinctione. Hec opinio tenet quod" in originali peccato duo considerantur unum tanquam materiale scilicet concupiscentia que est qualitas quedam morbida maxime illa que inheret anime. Aliud est formale et est carentia iusticie originalis debite.

Alexander of Hales, Summa Sententiarum II, q. 122 introduced the formula that became common of the material and formal element. Cf. A. Gaudel, "Péché Originel," DTC, 12 (1933), col. 460.

7 Loc. Cit.;

Sicut in peccato actuali similiter duo sunt. Gratia exempli in homicidio est aliquid positivum in anima scilicet quidam actus elicitus a voluntate qui est velle occidere. In exteriore vero ipse actus occidendi. Formale est privatio scilicet carentia iusticie debite inesse illi actui. Que si inesset actui interiori sive exterior non esset peccatum.

My concern is not with Alexander of Hales.

8 Loc. Cit.:

Beatus Thomas ubi supra articulo primo dicit peccatum originale habet privationem originalis iusticie et cum hoc inordinatam dispositionem partium anime. Unde non est privatio pura, sed est quidam habitus corruptus. Non tamen habitus infusus aut acquisitus sed habitus per viciatum originem innatus. Et articulo tertio dicit peccatum originale materialiter quidem est concupiscentia, formaliter autem est defectus originalis iusticie.

Biel refers to Summa I-II, q. 82, art. 1 and art. 3. 
9 Loc. Cit.:

Non enim excludit magister privationem iusticie originalis a peccato originali. Nec negat beatus Anselmus qualitatem morbidam scilicet concupiscibilitatem contrahi in filiis a carne infecta parentis, licet sub illis vocabulis non exprimit.

Here Biel clearly misinterprets Anselm by ascribing to him this doctrine of the morbid quality. Anselm does not rely on any doctrine of the pollution of the flesh through lustful concupiscence.

10 St. Thomas Aquinas Summa Theologiae Original Sin (1a $\left.2^{a e}, 81-85\right)$, trans. and ed. T.C. O'Brien, O.P., St. Thomas Aquinas Summa Theologiae, Vol. 26 (London: Blackfriars, 1965). English and Latin texts of the Summa are taken from this edition, hereafter cited as St. Thomas. ST I-II, q. 82, art. 1, ad 1; St. Thomas, p. 29.

$11 \mathrm{Ibid}$., ad 1; St. Thomas, p. 31. Biel's quotation matches exactly the final sentence of St. Thomas (St. Thomas, p. 30), "Unde non est privatio pura, sed est quidam habitus comuptus."

12 The second objection and its answer are also worth noting (Loc. Cit.):

2. Further, actual sin is more culpable than original sin, in that it is more voluntary. But a habit of actual sin is not itself a sin; otherwise a person with such a habit would be sinning even while sleeping. Thus no original habit could be culpable.

2. Actual sin is disorder in an act; original sin as a sin of nature is a kind of disordered disposition in human nature and is sinful by reason of its derivation from the first parents, as has been said. This disordered disposition does have the character of a habit, whereas the disordered disposition in an act does not. For this reason it is possible for original sin, but not actual sin, to be a habit.

13 lbid., ad 3; St. Thomas, p. 29.

14 Ibid., ad 3; St. Thomas, p. 33. Here Biel reports accurately but not verbatim St. Thomas' words (St. Thomas, p. 32), "Nec debet dici quod peccatum originale sit habitus infusus aut acquisitus per actum (nisi primi parentis, non autem hujus personae), sed per vitiatam originem innatus."

15 Loc. Cit., St. Thomas, p. 31.

16 Loc. Cit., St. Thomas, p. 31.

17 II Sent., d. 30, cap. 8. See text below under note 28.

18 St. Thomas treats habits at some length in ST I-II, q. 49-54. Following Aristotle, he categorizes habit as quality and gives this definition, "Habit is a disposition whereby that which is disposed is disposed well or ill, and this, either in regard to itself or in regard to another: thus health is a habit" (q. 49, art. 1). Habit, as opposed to disposition, is difficult to change (q. 49, art. 2, ad 3). Health and sickness and beauty are habits in relation to nature, are habits in the body, do not have the nature of habit perfectly (q. 50 , art. 1), cannot be in the soul (q. 50, art. 2) which as form already completes human nature. Habits like sickness and health can have natural or extrinsic causes (q. 51, art. 1). Health can increase or decrease (q. 52, art.1) as a quality and form. St. Thomas expressly treats the corruption of habits in q. 53, art. 1: health and sickness are contrary forms $(\operatorname{ad} 2)$ and one corrupts the other ( $\operatorname{ad} 2$ and ad c.). Virtues (q. 55) and vices (q. 71) are operative habits which dispose a power well or ill in its action. They are clearly positive. It seems clear that St. Thomas, following Aristotle, conceives (entative) habits that dispose well or ill in relation to nature as positive. Throughout, health and sickness are linked together as habits. Cf. A. Michel, "vertu," DTC, 15-1 (1944), esp. cols. 2753-54. On the varied usage of disposition in scholasticism cf. M. Stock, "Disposition," New Catholic Encylocpedia 4, 907-908.

19 Ibid., art. 3, ad c.; St. Thomas, p. 39.

20 St. Thomas, p. 37, note a.

21 St. Thomas, p. 39, note q. See also p. 38, note f. The question of concupiscence appears again in q. 85 , art. 3.

22 O. Lottin, "Les Théories sur le Péché originel de saint Anselme à saint Thomas d'Aquin," Psychologie et Morale aux XII' et XIII Siècles, Tome IV, Part 1 (Louvain, 1954), p. 249, note 1. See also p. 274. St. Thomas used Albert and Bonaventure but not Alexander of Hales (p. 269).

23 See p. 249 , note 1 ; p. 265 ; p. 271 ; p. 274-75.

24 Ibid., p. 267.

25 ST I-II, q. 82, art. 3, ad c.; St. Thomas, p. 39.

26 Loc. Cit. Biel's position in q. 1 is the same. 


\section{0 / Renaissance and Reformation}

27 Biel, it should be noted, in his argumentation indicates that St. Anselm too does not entirely neglect concupiscence. See below note 29 .

28 Ibid., q. 2, art. 1:

Opinio magistri hec videtur esse quod voluntas Ade peccans in carne sua causavit quandam qualitatem morbidam consequentem curvitatem voluntatis. Que variis nominibus nominatur. Dicitur enim fomes peccati, concupiscentia vel concupiscibilitas, lex membrorum, languor nature, tyrannus in membris, lex carnis. Et est sicut pondus quoddam in carne excitans motus sensuales et inclinans animam ad condelectandum carni et ita retardans et reprimens a delectationibus spiritualibus secundum illud Sap 9 Corpus quod corrumpitur aggravat animam. Aggravat propter istam qualitatem mobidam in carne. Et secundum quosdam illa qualitas non remittitur in essentia sua licet in effectu minuatur. Hoc est licet gratia tanta possit esse in anima quod magis inclinet ad superiora quam fomes ad inferiora, non tamen remittit fomitem quo ad essentiam quia non contrariatur fomiti que est in carne. Gratia autem est in anima quemadmodum si lapillus alligaretur alis avis quantumcumque cresceret vis motiva in ala nunquam minueretur gravitas lapidis. Licet quantum ad effectum munus posset deprimere et volatum avis impedire quia virtus contraria vinceret in effectu.

29 Loc. Cit.:

Ab illa autem morbida qualitate carnis in infusione anime causatur alia qualitas morbida in anima que est vitium inclinans animam ad effrenate concupiscendum. De quo dicit Augustinus quod facit parvulum habilem ad concupiscendum, adultum vero actu concupiscentem. Et utraque qualitas vocatur concupiscentia seu concupiscibilitas fomes etc. Et ista concupiscibilitas in anima est peccatum originale, non illa qualitas morbida in carne que est effectus peccati id est pena et peccati originalis causa. Et licet sine qualitate sua aut carnis voluntas naturaliter esset prona ad concupiscendum et condelectandum sensui, ut precedenti questione probatum est, non tamen a deo effrenate et generaliter sicut nunc.

30 Loc. Cit.:

Et ita patet secundum hanc opinionem quid sit peccatum originale secundum rem quia est qualitas morbida anime vitium scilicet concupiscentie. ...

31 Cf. Ibid., art. 3, doubt 1:

[For the Master] It will also be difficult to save the fact that God does not cause sin. For God, who is cause of every positive effect, causes whatever is positive in the tinder which that opinion holds to be original sin. [Difficile etiam erit salvare quod deus non causet peccatum. Quia quicquid positivum est in fomite quem ponit illa opinio esse peccatum originale deus causat qui est causa omnis effectus positivi.]

Biel sees that the Master's position, by making original sin something positive, could be considered Manichean and heretical, Cf. art. 2, concl. 6.

32 See above note 6.

33 Loc. Cit.:

Et hec videtur esse intentio Alexandri loco allegato dicentis quod originale peccatum habet utrumque culpam et penam. Culpa est carentia iusticie seu difformitas quedam qua ipsa anima deformatur. Concupiscentia est ipsa pena. Et infra cum dicitur peccatum originale est ipsa concupiscentia materialis et predicatio, formalis autem cum dicitur macula vel difformitas ex origine primorum parentum contracta. Et sequitur originale secundum aliquid est pena secundum aliquid est culpa. Ratione carentie iusticie est culpa. Ratione concupiscentie est pena.

34 Ponit ergo aliquid in corpore, aliquid in anima et cum hoc iusticie debitum que tria dicit manere in propagato. Non ergo negat positivum aliquod sequi peccatum primorum parentum tam in corpore quam in anima propagati.

Biel sees that Anselm expressly mentions "the weakness and corruption of the body" and "the carnal affections of the soul from the corruption of the body":

Ecce ubi expresse Anselmus trium facit mentionem scilicet infirmatatis et corruptionis corporis, carnalium affectuum anime ex corruptione corporis, quod intelligere oportet non de actuali affectu alioquin non esset in parvulis sed aptitudinale. Et tertio debitum iusticie et satisfactionis pro eius desertione.

Another paper would be necessary to determine whether Biel has correctly understood St. Anselm. In this argument Biel presumes that St. Anselm agrees with the teaching of Peter Lombard about the stained flesh. This view, I would argue, is not correct.

35 Loc. Cit.:

Unde videtur quod magis fit disputatio de nomine quam de re. 


\section{Renaissance et Réforme / 41}

36 St I-II, q. 83, art, 1 ad c.; St. Thomas, p. 47. See also q. 81 ad 2, 3, 4; 83, art. 1, ad 2, 3, 4; in q. 82, art 4 ad 3 St. Thomas clearly rejects transmission of original sin through actual sexual passion.

37 Ibid.; q. 81 art. 2.

38 T.C. O'Brien, O.P., St. Thomas, p. 130. The basic text of St. Thomas is q. 81 , art, 1, ad c. where he explicitly rejects explanation through bodily effects.

39 Ibid., p. 131.

40 Cf. James L. Connor, S.J. “Original Sin: Contemporary Approaches,” TS, 29 (1968), 215-40; Brian O. McDermott, S.J., "Original Sin; Recent Developments," TS, 38 (1977), 478-512. George J. Dyer, "Original Sin: Theological Abstraction or Dark Reality?" Catholic Mind, 77 (1979), 11-23; G. Vandervelde, Original Sin (Amsterdam, 1975).

41 For detailed study, see my article cited in note 3 above.

42 Cf. Alfred Vanneste, The Dogma of Original Sin, trans. E.P. Collins (Paris, 1973), pp. 119-133. O'Brien, St. Thomas, p. 118 states that Trent left the dispute unresolved as to whether original sin is concupiscence:

Of the removal of original sin the Canon [Canon 5] simply states that all that has the true nature and proper character of sin is taken away. Left unresolved, then, is the age-old dispute as to whether original sin consists in the absence of original justice or in concupiscence. It is true that the fifth error echoes Luther's description of original sin as consisting in concupiscence. The council allows that concupiscence does remain in the baptized, but insists that there is nothing sinful in it. The inference may be drawn that original sin in the non-baptized does not consist in concupiscence.

But this seems incorrect. At the end of Canon V the bishops anathematize those who claim concupiscence is truly and properly sin (DB 1515). Cf. K. Rahner, "Original Sin" in Sacramentum Mundi, V (Montreal, 1969) p. 329:

The Council of Trent defined (with the Reformers) a real inward original sin in all (except Mary), which is caused by Adam's sin, is really effaced by justification and (against the Reformers) does NOT consist in concupiscence, since this persists in the justified, but in the lack of original righteousness (justice) and holiness, which the Council regarded as constituted by the grace of justification as interior and habitual.

43 O. Brien, St. Thomas, p. 118:

Canon 5 of Trent presents two elements relevant to the nature of original sin; baptism's removal of its total guilt, and the condition of concupiscence remaining in the baptized. Two errors are rejected, the Lutheran theory of non-imputation, and the theological opinion that the remains of original sin keep something of sin about them even after baptism.

Cf. Paul Empie and William W. Baum, eds., One Baptism for the Remission of Sins, Lutherans and Catholics in Dialogue, Vol. 2 (Washington-New York, 1966). On p. 85 the editors conclude:

We are reasonably certain that the teachings of our respective traditions regarding Baptism are in substantial agreement, and this opinion has been confirmed at this meeting.

Cf. H. Meyer, "La Doctrine de la justification dans le dialogue interconfessionel mené par l'Église Luthérienne," Revue d' Histoire et de Philosophie Religieuses 57 (1977), 19-51. An equally important question is why Luther returned to St. Augustine's doctrine. The answer is connected to Luther's central doctrine of the enslaved will. Cf. McSorley, Luther Right or Wrong? Luther rejected in his teachers Biel and Ockham a semipelagian doctrine of grace, i.e., he became convinced that Biel exaggerated fallen man's capacity for good. Oberman, The Harvest, p. 426, agrees.

44 See especially the articles of V. Pfnür and W. Pannenberg in Joseph A. Burgess, ed., The Role of the Augsburg Confession (Phila., 1980). 